\title{
AS RELAÇÕES ENTRE O TRIBUNAL DE JUSTIÇA DA UE E OS TRIBUNAIS CONSTITUCIONAIS NACIONAIS DOS ESTADOS-MEMBROS*
}

\author{
FRANCISCO BALAGUER CALLEJÓN**
}

\begin{abstract}
RESUMO: Os Tribunais Constitucionais nacionais são actores directos (e não meros convidados) no processo de integração e actuam como tal, gerando novos impulsos que propiciam avanços importantes no processo de constitucionalização. Dessa forma, no contexto do Tratado de Lisboa, do direito constitucional interno e da integração, dois questionamentos são focados: o debate sobre se a União Europeia necessita de uma Constituição e que tipo de Constituição é adequada para avançar no processo de integração; e a determinação das condições estruturais nas quais se desenvolve hoje a actividade dos Tribunais Constitucionais e em que medida essas condições podem propiciar o avanço do processo de integração e favorecer a solução de conflitos em todos os níveis. Conclui-se pela necessidade de actuar em dois níveis, tornando o Direito Constitucional interno mais europeu e o Direito europeu mais constitucional.
\end{abstract}

PALAVRAS-CHAVES: Tratado de Lisboa; União Européia; Direito Constitucional; Integração.

ABSTRACT: National constitutional courts are actors directly involved in (and not merely invited to) the integration process and act as such, generating new impulses which enable important advances in the constitutionalization process. Therefore, in the context of the Treaty of Lisbon, of national constitutional law and of integration, two issues are focused: the debate on whether the European Union needs a constitution and what kind of constitution is adequate to advance the integration process; and determining the structural conditions in which the activity of constitutional courts is currently developed, as well as the extent to which such conditions may allow for the advance in the integration process and favor conflict-resolution in all levels. It can be concluded that it is necessary to act on two levels, making national constitutional law more European and European law more constitutional.

KEYWORDS: Treaty of Lisbon; European Union; Constitutional Law; Integration.

SUMÁRIO: Introdução; 1. Tribunal de Justiça e Tribunais Constitucionais; 2. O nível (pré)constitucional da União Europeia; 3. O Direito Europeu, o Direito Constitucional e o Direito Constitucional Europeu; 4. O contributo do Tratado de Lisboa para a relação entre o Tribunal de Justiça e os Tribunais Constitucionais dos Estados-Membros; 5. As condições estruturais do diálogo entre os Tribunais Constitucionais e o Tribunal de Justiça; Referências.

Artigo recebido em 24.07.2010. Artigo aceito para publicação em 6.01.2011 mediante convite.

* Traduzido do castelhano por Mariana Rodrigues Canotilho.

** Professor Catedrático de Direito Constitucional da Universidade de Granada, Espanha. 
SUMMARY: Introduction; 1. Court of Justice and Constitutional Courts; 2. The European Union's (pre)constitutional level; 3. European Law, Constitutional Law and European Constitutional Law; 4. The Lisbon Treaty's contribution for the relation between the Court of Justice and the Constitutional Courts of Member-states; 5 . The structural conditions of the dialogue between the Constitutional Courts and the Court of Justice; References.

\section{INTRODUÇÃO}

A relação entre a Justiça constitucional e o processo de integração europeia conduz-nos, de maneira natural, aos grandes problemas que hoje coloca o processo de integração. Isto sucede porque os tribunais constitucionais desempenham as suas funções em relação ao corpo jurídico que têm que interpretar e aplicar. Por esse motivo, a relação entre o ordenamento europeu e os ordenamentos nacionais articula-se, nos seus elementos essenciais, através da relação entre o Tribunal de Justiça e os tribunais constitucionais nacionais. Os tribunais não assumem um papel passivo, como é lógico, no desenvolvimento dessa importante função, mas não há dúvidas de que a conformação de cada ordenamento e das suas relações são elementos que determinam de que modo actuam os tribunais e de que maneira podem orientar a sua actividade. Daí que a relação entre tribunais e processo de integração apele, na realidade, a um universo de problemas que estão para além da mera actividade judicial, que a condicionam e a superam.

O debate sobre se a União Europeia necessita de uma Constituição e que tipo de Constituição é adequada para avançar no processo de integração é o primeiro destes problemas, cuja envergadura é desalentadora. Este debate não desapareceu com a entrada em vigor do Tratado de Lisboa, a 1 de Dezembro de 2009, e não podemos deixar de colocá-lo porque, em função da resposta que demos a esta questão, poderemos continuar a avançar na compreensão das relações entre ordenamento europeu e ordenamentos estaduais. A partir daí, poderemos abordar a última questão que nos preocupa e que está mais estreitamente relacionada com o título desta exposição: as condições estruturais nas quais se desenvolve hoje a actividade dos tribunais constitucionais e em que medida essas condições podem propiciar o avanço do processo de integração e favorecer a solução de conflitos em todos os níveis (com critérios aceites por todas as partes, algo essencial para a plena realização do princípio da segurança jurídica).

Naturalmente, no desenvolvimento destas questões não se pode pretender dar uma resposta que seja útil para compreender melhor as relações entre o ordenamento europeu e todos e cada um dos ordenamentos nacionais dos Estados-Membros. Esta tarefa resulta impossível actualmente devido à heterogeneidade dos ordenamentos nacionais. Heterogeneidade que afecta, entre muitos outros âmbitos, a própria existência de jurisdição constitucional ${ }^{1}$. Onde não exista jurisdição constitucional não

\footnotetext{
${ }^{1}$ Como indica Pedro Cruz Villalón, partindo desta heterogeneidade, “cualquier cosa que se proponga en relación con el papel de los Tribunales Constitucionales nacionales, en plural, siempre tendrá un valor relativo, en cuanto efectuada desde una determinada perspectiva nacional. Por otra parte, sin embargo, la circunstancia de que se esté hablando desde la perspectiva de un diseño enmarcado en el modelo mayoritario en la Unión de la garantía constitucional nacional permite esperar una proyección de esta reflexión que resulte plausible más allá del ordenamiento singular del que se parte”. Pedro Cruz Villalón, “El papel de los tribunales constitucionales nacionales en el futuro constitucional de la Unión” (2003), na compilação do mesmo autor, La Constitución inédita. Estudios ante la constitucionalización de Europa, Editorial Trotta, Madrid, 2004, p. 71.
} 
poderá visualizar-se uma relação dialéctica entre ordenamentos do tipo da que se produziu entre alguns tribunais constitucionais nacionais (em particular, o Tribunal Constitucional Federal alemão e o Tribunal Constitucional italiano) e o Direito Europeu.

Por isso, a reflexão sobre este tema não pode estender-se ao conjunto dos Estados-Membros, apesar de ser necessária, se tivermos em conta que os tribunais constitucionais nacionais são actores directos (e não meros convidados) no processo de integração e que actuaram como tal, gerando novos impulsos que propiciaram avanços importantes no processo de constitucionalização ${ }^{2}$. Se podem continuar a sê-lo no futuro e em que condições é uma das questões sobre as quais temos agora que procurar reflectir.

\section{TRIBUNAL DE JUSTIÇA E TRIBUNAIS CONSTITUCIONAIS}

1.1. Justiça Constitucional, Tribunal de Justiça e Tribunais Constitucionais

A primeira questão que deveríamos colocar-nos, quanto à relação entre Justiça Constitucional e processo de integração europeia, é o que entendemos por justiça constitucional. Seguramente, a resposta mais normal a esta pergunta seria a de que por justiça constitucional entendemos os tribunais constitucionais estatais ou nacionais. Incluir nesta definição o Tribunal de Justiça suporia já uma opção importante, já que ao outorgar-lhe o status de tribunal constitucional estaríamos a reconhecer implicitamente que o sistema normativo que tem que garantir é uma Constituição. No entanto, como veremos, o Tribunal de Justiça é algo mais do que um tribunal constitucional, precisamente porque o sistema normativo que tem que garantir ainda não é uma Constituição.

Não vamos, portanto, dar esse passo ou, pelo menos, não o daremos ainda. Não é possível deixar de reconhecer que o Tribunal de Justiça desenvolve importantes funções que são análogas às que correspondem aos tribunais constitucionais nacionais. Não creio que isto se possa negar. A questão está, porém, no facto de essas funções se desenvolverem num contexto normativo e ordenamental que fazem do Tribunal de Justiça algo mais do que um tribunal constitucional ${ }^{3}$. Nenhum tribunal constitucional nacional, por importante e decisivo que possa ter sido o seu trabalho de interpretação da Constituição nacional, teve, nem poderia ter tido, um papel tão intenso de configuração da ordem constitucional como o que teve o Tribunal de Justiça na conformação do ordenamento comunitário europeu.

2 “El Tribunal de Justicia no fue el único actor del proceso de constitucionalización: su jurisprudencia constitucional se elaboró en el marco de un diálogo con los jueces y tribunales nacionales, con las demás instituciones comunitarias y con los Estados miembros”, Gil Carlos Rodríguez Iglesias, Julio Baquero Cruz, "Funciones constitucionales del Tribunal de Justicia de las Comunidades Europeas", in Fundamentos, $\mathrm{n}^{\circ}$ 4, Junta General del Principado de Asturias, 2006, p. 300.

${ }^{3}$ Francisco Balaguer Callejón, "Livelli istituzionali e tecniche di riconoscimento dei diritti in Europa. Una prospettiva costituzionale”, in Tecniche di garanzia dei diritti fondamentali, org. de Giancarlo Rolla, G. Giappichelli Editore, Torino, 2001, pp. 113-130. Versão espanhola na Revista de Derecho Constitucional Europeo, $n^{\circ}$ 1, Enero-Junio de 2004, pp. 25-46. Direcção electrónica: http://www.ugr.es/ redce/.; versão alemã: Jahrbuch des öffentlichen Rechts der Gegenwart, Mohr Siebeck, Tübingen, Bd. 53, 2005, pp. 411-428; versão francesa: Revue Française de Droit Constitutionnel, $n^{\circ}$ 60, Presses Universitaires de France, Paris, Octobre 2004, pp. 675-693 e versão portuguesa, Revista Seqüência, Universidade Federal de Santa Catarina, Florianópolis (Brasil) Ano XXV, nº 50, Jul. 2005, pp. 237-258. 
Esse papel tão intenso é consequência da inexistência de uma Constituição assente sobre um referente textual que permita uma ordenação sistemática e completa do nível constitucional da União Europeia. De momento, encontramo-nos com princípios que operam sobre uma ordem fragmentária e que, com tal, se podem qualificar como "normas sem disposição", no sentido de Crisafulli ${ }^{4}$. Estamos, portanto, ante uma Constituição "sem palavras", sem o referente textual sobre o qual assenta o labor dos tribunais constitucionais nos ordenamentos nacionais.

Esta diferença essencial entre Tribunal de Justiça e tribunais constitucionais deve-se a que, no Estado de direito constitucional no qual estes últimos desenvolvem o seu trabalho, a ordem constitucional se constrói com base num equilíbrio entre três agentes essenciais: constituinte, legislativo e jurisdicional, que interagem sobre um contexto previamente definido: as disposições e normas constitucionais. Os tribunais constitucionais nacionais produzem Direito sob determinadas condições estruturais que favorecem uma limitação do seu poder e, portanto, um equilíbrio na sua inserção no conjunto dos poderes públicos. Em relação ao legislador democrático, a produção dos tribunais constitucionais nacionais carece da plenitude própria da produção legal. A lei continua a ser o instrumento de conformação do ordenamento jurídico no Estado de direito constitucional e expressa o funcionamento normal dos mecanismos de produção jurídica. A jurisprudência tem um potencial corrector, que surge apenas no momento da resolução de conflitos. Assim, pois, a jurisprudência dos tribunais constitucionais nacionais é uma fonte de produção complementar do ordenamento jurídico.

Pelo contrário, o Tribunal de Justiça, ante a ausência de um pleno contexto constitucional, tem que realizar uma função constituinte própria em muitos âmbitos, ao ponto de ter sido o próprio Tribunal de Justiça a estabelecer os princípios fundamentais de articulação do ordenamento comunitário europeu e da sua relação com os ordenamentos nacionais (como é o caso do princípio do primado). Um exemplo paradigmático dessa função constituinte é a matéria dos Direitos Fundamentais, âmbito no qual o Tribunal de Justiça desenvolveu essa função constituinte incorporando direitos no ordenamento, essencialmente através do recurso a elementos externos ao próprio ordenamento comunitário (tradições constitucionais comuns dos Estados-Membros ou $\mathrm{CEDH})$. Mas, ao mesmo tempo, essa função constituinte tem uma vocação legislativa ${ }^{5}$ necessária para a realização dos direitos fundamentais, pelo que o TJCE tem que actuar simultaneamente no âmbito legislativo e no âmbito constituinte.

Fazendo um jogo de palavras, que tanto agradam aos juristas, poderia dizer-se que onde o Tribunal de Justiça desenvolveu a ordem constitucional não actuou como autêntico tribunal, mas sim exercitando uma função constituinte. Pelo contrário, quando actuou como autêntico tribunal, fê-lo em relação a um corpo normativo que não é

\footnotetext{
${ }^{4}$ Cfr. V. Crisafulli “Atto normativo”, EdD, tomo IV, 1959, pp. 258-260 e “Disposizione (e norma)” EdD, tomo XIII, 1964.

${ }^{5}$ Como indica Enrique Guillén, os avanços na democratização do sistema de fontes europeu devem produzir também uma mudança progressiva nas pautas interpretativas do Tribunal de Justiça, fazendo valer um princípio de presunção de constitucionalidade a favor do legislador democrático. Cfr. Enrique Guillén López, "El Parlamento Europeo”, in Revista de Derecho Constitucional Europeo, nº 3, Enero-Junio de 2005, pp. 57-85. Direcção electrónica: http://www.ugr.es/ redce/.
} 
estritamente "Direito constitucional”. Ou seja, quanto mais o Tribunal de Justiça se aproximou de matéria constitucional, mais deixou de ser tribunal, e quanto mais actuou como tribunal, mais se afastou da matéria constitucional. Isto deve dizer-se não como crítica ao Tribunal de Justiça, cujo impressionante labor na construção constitucional da Europa não pode deixar de ser reconhecido. Precisamente por isto, é impossível equipará-lo à jurisdição constitucional que intervém nos ordenamentos nacionais por referência a uma Constituição pré-existente em tensão dialéctica com um constituinte e um legislador democrático e em relação a uma comunidade política estruturada, num espaço público consolidado.

Tendo em conta estas diferenças essenciais entre Tribunal de Justiça e tribunais constitucionais, partiremos inicialmente da hipótese de que a relação entre Justiça Constitucional e processo de integração é, sobretudo, uma relação que afecta os tribunais constitucionais nacionais, na medida em resulta indubitável que têm essa condição de Justiça Constitucional no contexto ordenamental próprio de um Estado de direito constitucional. Com essa interpretação, que pode caracterizar-se como restritiva, do termo "Justiça Constitucional”, não deixamos, todavia, de fora, o Tribunal de Justiça, que continua a estar presente, inevitavelmente, no segundo termo dos dois em que se centra esta exposição: o processo de integração europeia.

O Tribunal de Justiça continua a estar presente porque a relação entre os tribunais constitucionais nacionais e o ordenamento europeu se manifesta, em grande medida, através do Tribunal de Justiça. De facto, como é sabido, essa relação deu lugar a importantes avanços em matéria de Direitos Fundamentais, motivados pelas reticências expressas pelos tribunais constitucionais nacionais e o consequente temor de que essas reticências pudessem conduzir a uma ruptura da unidade do direito europeu, na sua possível colisão com o Direito constitucional interno ${ }^{6}$. A ideia de um diálogo ou de uma cooperação entre os tribunais constitucionais e o Tribunal de Justiça, a que tanto se fez apelo nos últimos tempos, é também descritiva da necessidade de ter em conta o Tribunal de Justiça no núcleo do debate sobre a relação entre Justiça Constitucional (entendendo por tal a nacional ou estatal) e processo de integração europeia.

É justamente essa ideia de diálogo que nos vais permitir adoptar uma orientação específica nesta exposição, que deve começar a tentar esclarecer qual é a função que corresponde aos tribunais constitucionais em relação ao processo de integração europeia e qual é a função que corresponde ao Tribunal de Justiça em relação ao Direito constitucional.

\subsection{As funções do Tribunal de Justiça e dos Tribunais Constitucionais}

Ao situar os tribunais constitucionais no lado da justiça constitucional (pelo menos como ponto de partida) e o Tribunal de Justiça no lado do processo de integração europeia, fizemos algo que, por discutível que possa ser, é perfeitamente compreensível se tivermos em conta a função primordial que corresponde a cada um destes órgãos jurisdicionais. Enquanto tais, devem garantir a eficácia de um

${ }^{6}$ Cfr. Gregorio Cámara Villar, "Los Derechos Fundamentales en el proceso histórico de construcción de la Unión Europea y su valor en el Tratado Constitucional”, Revista de Derecho Constitucional Europeo, $\mathrm{n}^{\circ} 4$, Julio-Diciembre de 2005, pp. 9-42. Direcção electrónica: http://www.ugr.es/ redce/ 
sistema normativo que os vincula, nas condições e com os limites estabelecidos por esse sistema.

Com efeito, aos tribunais constitucionais corresponde, como função essencial, a garantia do seu ordenamento constitucional. Essa garantia da Constituição, da qual são os intérpretes supremos, resulta, em princípio, neutra em relação ao processo de

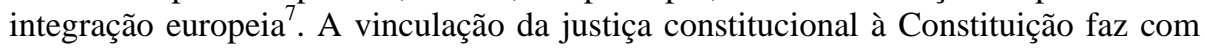
que o processo de integração europeia só possa ser objecto de juízo nas condições que estabeleça a própria Constituição e de acordo com as características gerais do sistema constitucional nacional. Não é o mesmo, por exemplo, que a Constituição não contenha previsões específicas em relação a esse processo, para além da habilitação genérica para que o Estado se incorpore ${ }^{8}$, ou que, pelo contrário, a Constituição estabeleça condições e limites (como ocorre na Alemanha). Tão-pouco é o mesmo, por exemplo, que a Constituição estabeleça limites à sua revisão, através de cláusulas de intangibilidade (limites materiais de revisão), como ocorre em Itália ou na Alemanha, ou que não contemple expressamente esse limites.

A relação entre o Direito Constitucional interno e o Direito europeu, bem como a relação entre os tribunais constitucionais e o Tribunal de Justiça, está condicionada, como é lógico, pela relação prévia que cada um deles tem com o seu ordenamento e pela conformação específica de cada ordenamento. Isto vale também para o Direito europeu, como já demonstraram os tribunais constitucionais que, desde o princípio, definiram as suas reticências a respeito do Direito Europeu em função da conformação específica deste último e da sua inadequação, considerada provisória, aos mecanismos de garantia constitucional, especialmente em relação aos direitos fundamentais.

Em última instância, essa relação não pode ser alterada de maneira incondicional por qualquer dos órgãos jurisdicionais, o Tribunal de Justiça e o tribunal constitucional nacional de cada Estado Membro. Pelo contrário, será a conformação concreta de cada ordenamento jurídico que a definirá. Daí que o diálogo concreto entre os tribunais tenha já limites e condições de partida. Pela via do diálogo entre jurisdições não se podem solucionar os problemas de conformação de cada ordenamento jurídico e as relações entre eles.

É necessário reconhecer, portanto, que há umas condições estruturais do diálogo, ou seja, da tensão dialéctica entre os tribunais constitucionais e europeu. Essas condições estruturais não dependem das jurisdições, mas sim de como se configuram os sistemas jurídicos nos quais exercem as suas funções. Por esse motivo, é necessário abordar a questão da conformação dos sistemas jurídicos no seu nível máximo, que

\footnotetext{
${ }^{7}$ Apesar disso, como indica Antonio La Pergola, devido à lógica do primado do Direito comunitário, configuraram-se como "potenciais antagonistas" do Tribunal de Justiça, que considera o seu ordenamento destinado a prevalecer sobre o do Estado. Cfr. Antonio La Pergola, "El Juez Constitucional italiano ante la primacía y el efecto directo del derecho comunitario. Notas sobre unas jornadas de estudio”, in Ninon Colneric, David Edgard, Jean-Pierre Puissochet, Dámaso Ruiz-Jarabo Colomer (Hrsg.), Une communauté de droit, Festschrift für Gil Carlos Rodríguez Iglesias, Berliner Wissenschafts Verlag, Berlin, 2003, pp. 255.

${ }^{8}$ Como sucede em Espanha. Cfr., sobre as propostas de reforma, Francisco Rubio Llorente, José Alvarez Junco (eds.) El informe del Consejo de Estado sobre la reforma constitucional. Texto del informe y debates académicos, CEPC, Madrid, 2006.
} 
não é outro senão o nível constitucional. Isso conduz-nos, de momento, a colocar a grande questão do nível constitucional (ou pré-constitucional) da União Europeia.

\section{O NÍVEL (PRÉ)CONSTITUCIONAL DA UNIÃO EUROPEIA}

\subsection{Medo da Constituição?}

Inevitavelmente, temos que partir de uma situação que provoca uma inevitável perplexidade nos constitucionalistas e nos cidadãos: da desconfiança em relação ao termo "Constituição"9. O receio em relação a este termo é surpreendente se se comparar com o alto prestígio que teve no mundo moderno e que continua a ter dentro dos ordenamentos nacionais. O mais surpreendente é a dupla linguagem que se utiliza em alguns sectores a respeito do termo “Constituição”. Por um lado, descarta-se a sua utilidade no processo de integração europeia pela sua conexão com o Estado nacional e, por outro, oferecem-se novos conceitos de Constituição já desvinculados - diz-se - desta conexão com o Estado nacional e mais adequados para a singular conformação do processo de integração europeia. Conceitos light, ou conceitos minimalistas de Constituição, como se a Constituição representasse um perigo a conjurar em relação à União Europeia ${ }^{10}$ (mas não em relação aos Estados, onde o seu prestígio permanece intacto).

Este receio face à Constituição deve-se a diversas razões que têm que ver também com a atitude que os tribunais constitucionais adoptaram durante bastante tempo a respeito do processo de integração europeia. A primeira delas está relacionada com a aparente debilidade do Estado nacional, aspecto sobre o qual nos deteremos seguidamente.

2.2. O reforço da Soberania Estadual Interna através das Instâncias Supranacionais

O contexto geral do "medo da Constituição" deve situar-se nas condições objectivas nas quais o processo de integração europeia se desenvolveu até agora. Ao contrário do que habitualmente se vem afirmando quando se diz que o processo de integração europeia é e tem sido uma manifestação da debilidade do Estado nacional, creio que devemos situar-nos na hipótese exactamente contrária: o processo de integração foi até agora uma manifestação evidente da força do Estado nacional. O processo de integração não supôs uma diminuição da soberania do Estado, tendo, sim, tornado possível um reforço do Estado, se tivermos em conta as limitações que para o poder político supunham os processos de globalização e democratização. Se o processo de integração continuar a decorrer nos mesmos moldes em que o fez

\footnotetext{
${ }^{9}$ Como indica Pedro Cruz Villalón, uma primeira dificuldade do debate constitucional na União Europeia está em explicar que a dotação de uma Constituição para a Europa seja um problema. Cfr. Pedro Cruz Villalón, “La Constitución inédita. La dificultad del debate constitucional europeo” (2002), na compilação do mesmo autor, La Constitución inédita. Estudios ante la constitucionalización de Europa, cit., p. 22.

${ }^{10} \mathrm{Um}$ exemplo paradigmático pode ser encontrado em J.H.H. Weiler que chega a dizer que "merece la pena escuchar cuidadosamente la retórica del discurso constitucional. Suena a marcha militar, incluso cuando la recitan grandes humanistas". J.H.H. Weiler, "El principio de tolerancia constitucional: la dimensión espiritual de la integración europea”, versão espanhola de Miguel Azpitarte Sánchez, in Francisco Balaguer Callejón (Coordinador) Derecho constitucional y cultura. Estudios en Homenaje a Peter Häberle, Tecnos, Madrid, 2004, p. 113.
} 
até agora, o Estado nacional continuará a ser, por muitos anos, o referente da política europeia e terá conseguido ultrapassar muitos dos obstáculos que a globalização, no plano mundial, e a democratização e tensões territoriais, no plano interno, colocaram no seu caminho.

Uma das características do Estado nacional é que soube combinar a limitação da soberania e a realização dos princípios democráticos no âmbito interno com o exercício da soberania e a ausência de subordinação a critérios democráticos na sua actuação externa, na sua actuação internacional ${ }^{11}$.

Desde essa perspectiva, bem poderíamos dizer que a limitação supranacional da soberania externa do Estado no âmbito da União Europeia não contribuiu para incrementar a qualidade democrática interna dos Estados-Membros, mas, bem pelo contrário, para diminuir essa qualidade democrática.

Isto é assim porque os Estados-Membros conseguiram, graças ao processo de integração e através da transferência de competências para uma organização supranacional, exercer no âmbito interno a soberania que não podiam exercer anteriormente, pela sua necessária subordinação às condições do Estado de direito democrático. O processo de integração favoreceu que os governantes europeus possam realizar, pelo menos parcialmente, o sonho de muitos políticos: exercer poder sem responsabilidade. Há que tomar em conta que o processo de integração está unido historicamente aos processos de democratização interna (com limitações jurídicas ao poder do Estado através de constituições normativas) e de globalização (a segunda globalização, que começa na década de 50 do século XX e que se desenvolveu de maneira acelerada nos últimos anos). Ambos os processos levarão a que o Estado perda poder político tanto no âmbito interno como no externo. Esse poder político será recuperado em parte graças ao processo de integração europeia, que aparece assim na sua própria conformação genética como uma resposta dos Estados face aos processos de democratização e globalização.

Ao transladar as competências para uma organização supranacional submetida basicamente aos procedimentos de adopção de decisões do Direito Internacional ${ }^{12}$ e, portanto, aos procedimentos de adopção de decisões do Direito Internacional baseados na soberania dos Estados, os Estados-Membros puderam transferir para as instâncias europeias a adopção de decisões problemáticas no âmbito interno, deslocando a responsabilidade para instâncias nas quais, em última instância, o

${ }^{11}$ Como indica Luigi Ferrajoli, "Mientras el estado-nación liberal-democrático se basaba internamente en la sujeción de todos los poderes públicos al Estado de Derecho y a la representación popular, en sus relaciones externas se mantenía libre de todo límite legal”. Luigi Ferrajoli, "Más allá de la soberanía y de la ciudadanía: un constitucionalismo global”, publicado inicialmente na obra colectiva Constitutionalism, democracy and sovereignity, editado por Richard Bellamy, Avebury, 1996. Tradução do inglês de Gerardo Pisarello, ISONOMÍA, n. 9, octubre de 1998, pp. 175.

${ }^{12}$ Como indica Fulco Lanchester: "unanimità e veto (con la mitigazione della predetta astensione costruttiva) costituiscano, dal punto di vista teorico, la negazione dell'esistenza di un ordinamento pubblico interno, richiamando l'ambito del diritto internazionale pubblico; e dal punto di vista pratico siano emblematiche delle dificoltà del processo di integrazione”. "La Carta europea dei diritti fondamentali tra aspirazioni e realtà”, in AA.VV. Sfera pubblica e Costituzione europea, Carocci editore, Roma, 2002, pp. 76. 
poder se esconde ${ }^{13}$. Esta forma de actuar apresenta inegáveis vantagens, especialmente em tempos de mudanças, reconversões e actuações limitadoras dos direitos sociais que inspiraram o constitucionalismo do Estado social, do grande pacto social que em muitos países europeus deu lugar ao Estado de direito constitucional. Os Estados decidiram conjuntamente na Europa através de mecanismos supranacionais (confederais, se quisermos), subtraindo essas decisões ao seu espaço constitucional e ao debate público nacional, e obrigando-se a cumpri-las através da sua inserção num sistema jurídico federal que os vinculava por meio do princípio do primado ${ }^{14}$.

Estarão os governantes europeus dispostos a renunciar a estas vantagens e em que condições? Esta é a grande pergunta que nos podemos fazer hoje se tivermos em conta que os impulsos essenciais que podem fazer avançar o processo dependem deles. Coloca-se aqui a grande incerteza que deriva da consideração de uma oposição e até de um conflito insanável entre o constitucionalismo dos Estados-Membros e o processo de integração europeia, que está na base de muitas construções que pretendem desvincular ambos os processos, o constitucional e o europeu. Estas construções conduzem à manutenção de métodos convencionais de negociação e adopção de decisões, inspirados no Direito Internacional que resultam claramente em contradição com a consolidação de uma comunidade política europeia baseada em critérios democráticos de adopção de decisões. Em última instância, levam a que na contraposição essencial entre os agentes sobre os quais pretende assentar-se o processo de integração, a cidadania e os Estados, continue a dar-se preferência aos Estados, com correç̧ões mais ou menos intensas (como a participação dos parlamentos nacionais) que não podem supor uma evolução democrática porque continuam a inspirar-se numa mesma filosofia: a tutela pelos Estados do processo de integração.

Esta contradição aparente entre Direito constitucional e processo de integração europeia deveria ter, sem embargo, os dias contados. Conforme avança o processo de integração e se produz a ampliação progressiva da União Europeia, resulta claramente insuficiente o método de adopção de decisões desenhado para uma estrutura supranacional muito mais reduzida. Por outro lado, o desenvolvimento acelerado do processo de globalização situa os Estados europeus diante de uma alternativa iniludível: ter uma voz europeia comum no contexto internacional ou carecer de presença relevante como agente mundial, já que nenhum dos Estados-Membros a terá por si só

${ }^{13}$ Uso a expressão de Cesare Pinelli: "Dal punto di vista costituzionale, ciò che conta è el principio di corrispondenza fra potere e responsabilità, che non può considerarse disponibile se non a costo di una forte regressione della democrazia. Quando perciò le sedi del potere si articolano, si frammentano e magari si nascondono, como sta avvenendo ovunque ben al di là della divisione nei tre livelli sovranazionale, nazionale e regionale, il costituzionalista dovrebbe andarle a cercare, per individuare corrispondenti e più adeguate forme di responsabilità per l'esercizio del potere", Cesare Pinelli, "Multilevel Constitutionalism e principi fondativi degli ordinamenti sopranazionali”, p. 7. http://www.giuripol.unimi.it/eventi/Pinelli \%20Milano.

${ }^{14}$ Weiler explica-nos claramente a situação, ainda que não nos termos críticos com os quais a estamos analisando, de uma perspectiva constitucional. Como indica Weiler, na União Europeia existe uma primazia (ele chama-a hierarquia) normativa do Direito europeu sobre o estatal, mas não uma hierarquia de potestades ou de poder real, já que enquanto que o primado se constrói de cima para baixo (da União sobre os Estados), a hierarquia de poder real constrói-se de baixo para cima (dos Estados sobre a União). Definitivamente, o poder real continua a ser dos Estados, o que caracteriza o sonderweg europeu, a sua forma e identidade especial: a combinação de uma ordenação institucional confederal e uma ordenação legal federal (cfr. op. cit., pp. 107-108). 
no prazo de três décadas. O controlo pelos Estados do processo vai sendo cada vez menor e a necessidade de construir um espaço constitucional de decisão, baseado numa comunidade política articulada em torno da cidadania europeia revela-se cada vez mais urgente. A aparente contradição entre constitucionalismo e europeísmo (entendido na tónica estatal e, portanto, não como autêntico europeísmo) deve dissolver-se progressivamente para dar lugar à ideia de que a integração europeia só pode ser uma integração de natureza constitucional. Uma integração na qual os cidadãos europeus sejam os principais agentes.

\subsection{A reacção dos Tribunais Constitucionais em defesa da Constituição}

Se algumas das hipóteses anteriores estão correctas, ou ao menos se são aceitáveis enquanto tais, haveria que considerar também que quando se defende a ideia de que uma Constituição europeia não deve basear-se no modelo do Estado nacional, tal não obedece tanto ao temor de que a Constituição europeia seja o acto fundacional de um Estado federal europeu, quanto ao temos de que a Constituição europeia e o Estado federal europeu constituam o acto de defunção do Estado nacional e do mundo da política que hoje conhecemos na Europa. De maneira surpreendente, podemos ver a contradição que supõe não querer um modelo de Constituição que nos conduziria a um tipo de organização estatal que parece criticável e por isso não se quer utilizar como modelo, mas cuja única maneira de ser preservada é tornando possível que o Estado nacional subsista como tal e que continue a ser o referente do espaço constitucional nuclear. Ou seja, negando a transferência de categorias constitucionais e de técnicas de controlo para o âmbito europeu, para o qual previamente se transferiram competências estaduais, o que supõe prosseguir mantendo um Estado constitucional no âmbito interno (apesar das críticas que esse modelo suscita) que, além do mais, continua a exercer um poder não submetido a critérios constitucionais de controlo no âmbito supranacional.

Estas contradições explicam-se porque, na realidade, o Estado nacional não perdeu soberania através do processo de integração europeia, mas sim ganhou-a, como tentámos argumentar anteriormente. Ganhou-a no sentido de que graças à sua integração supranacional conseguiu elidir alguns dos limites internos à sua soberania estabelecidos constitucionalmente, através da deslocação das competências e da capacidade de decisão para instâncias supranacionais nas quais a vontade estatal é necessária para adoptar decisões.

Desse modo, o processo de integração foi funcional para os Estados e as classes políticas nacionais. Não o seria, desde essa perspectiva, se a lógica da integração se levasse às suas últimas consequências. Daí o medo à Constituição, que mais não é do que o medo da Europa, medo de uma culminação natural do processo de integração (porque o autêntico europeísmo só pode conduzir a uma comunidade política europeia e a um espaço constitucional europeu). Quando mais natural se evidencia essa culminação natural do processo, mais resistências provoca e mais necessário resulta “deslegitimar" o conceito de Constituição ou “desnaturalizá-lo", incorporando elementos estranhos que impedem que realize as suas autênticas funções.

Desta perspectiva, pode compreender-se perfeitamente o receio em relação à presença dos tribunais constitucionais nacionais no debate europeu. Num processo 
de integração que tornava possível elidir os controlos constitucionais internos, deslocando a responsabilidade para o âmbito europeu, a voz discordante dos tribunais constitucionais não era, como poderia parecer e como de facto se quis fazer ver, a de defesa das prerrogativas estaduais. Defender a constitucionalidade da actuação dos poderes públicos não é defender a soberania do Estado, mas sim defender a submissão do Estado a limites jurídicos que tinham, em grande medida, desaparecido (apesar do impressionante trabalho do Tribunal de Justiça), mediante a deslocação do poder de decisão para o âmbito europeu.

Ora, na medida em que a voz dos tribunais constitucionais internos só podia basear-se na Constituição nacional, a percepção tida desse protagonismo dos tribunais, desde o âmbito europeu, era o de uma opinião discordante em relação ao processo de integração. Não era assim, no entanto, porque estar a favor do controlo constitucional do poder não deveria ter-se considerado nunca como uma resistência frente ao processo de integração, mas sim como uma crítica à forma em que o processo de integração se vinha desenvolvendo.

Seja como for, essa resistência dos tribunais constitucionais criou uma imagem inexacta para eles e também uma falsa imagem da Constituição. A aparente oposição entre "Constituição" e "integração" que se gerou na ainda breve história do processo de integração é um dos factores que permite explicar o incompreensível desgaste do valor da Constituição no processo de integração europeia.

Em definitivo, o processo de integração tem vindo a desenvolver-se como uma actividade internacional ou supranacional do Estado, não como uma actividade constitucional do Estado. A desvinculação entre a actividade supranacional e a ordem constitucional tornou possível que o Estado exerça autêntica soberania no âmbito interno. O Estado conseguiu assim elidir os limites constitucionais e deslocar a responsabilidade para o âmbito supranacional, no qual não se verificavam as condições constitucionais de limitação do poder e de garantia dos direitos próprias da ordem constitucional interna. Esta orientação do processo de integração gerou um inevitável confronto entre essa actividade supranacional do Estado e a Constituição nacional.

Posto que esta situação de debilidade constitucional do ordenamento europeu foi funcional para o Estado, podemos aventurar-nos a afirmar que o medo em relação à realização do sonho europeu, através de uma plena integração política, mediante uma federação, não se produz porque esse sonho se possa converter num pesadelo com a criação de um super estado centralista e autoritário, mas é, sim, na realidade, medo da mera realização desse sonho, que suporia uma mudança inevitável nas condições actuais de exercício da política não só ao nível europeu, mas também nos níveis internos. É o medo não da criação de um super estado europeu, mas do desaparecimento do Estado nacional ou a sua conversão numa estrutura política subordinada às instâncias europeias e plenamente submetida a condições constitucionais de exercício do poder ${ }^{15}$. Porque o problema do deficit democrático e

${ }^{15}$ Como indica Antonio La Pergola, "El apego de todos los Estados miembros (grandes y pequeños) a la soberanía nacional bloquea actualmente la posibilidad real de que la integración conseguida hasta ahora desemboque en un superestado”. Op. cit., p. 252. 
constitucional $^{16}$ da União Europeia não é apenas o do exercício de um poder europeu não submetido a condições constitucionais no exterior do Estado, mas também (e sobretudo) o da desvinculação interna do Estado em relação a essas condições constitucionais a que estava submetido antes de transferir as competências que agora exercita indirectamente.

\section{O DIREITO EUROPEU, O DIREITO CONSTITUCIONAL E O DIREITO CONSTITUCIONAL EUROPEU}

Uma das condições estruturais que facilitariam o diálogo ou a dialéctica entre jurisdições, seria que ambas utilizassem a mesma linguagem jurídica. No entanto, isto não se passou assim até agora, já que o Tribunal de Justiça fala basicamente da perspectiva do Direito europeu, como não pode deixar de ser, enquanto que os tribunais constitucionais falam essencialmente da perspectiva do direito constitucional. Para que haja um autêntico diálogo, seria necessário que ambos falassem o mesmo idioma. A situação ideal seria, obviamente, a da convergência de ambos os termos, o "Direito europeu" e o "Direito constitucional", mediante a consolidação de um autêntico "Direito constitucional europeu".

Enquanto não ocorra tal coisa, é compreensível que o Tribunal de Justiça continue a cumprir a sua função de garantia do Direito europeu e os tribunais constitucionais nacionais a de garantia do Direito constitucional. Isto não quer dizer que o Direito europeu não seja já, em parte, constitucional, nem que o direito constitucional interno não seja já, em parte, europeu. A aproximação entre ambas as perspectivas foi um processo natural ${ }^{17}$, porque o Tribunal de Justiça teve que assumir técnicas constitucionais para cumprir as suas funções e os tribunais constitucionais tiveram que se incorporar na lógica europeia. Mas é evidente que nos encontramos no decurso de um processo que deverá sofrer um impulso decisivo com a entrada em vigor do Tratado de Lisboa, a 1 de Dezembro de 2009, no qual não se produziram ainda os ajustes necessários entre os diversos agentes.

Como vimos antes, a função que cabe a cada uma das jurisdições é diferente. Enquanto os tribunais constitucionais têm a missão de garantir o ordenamento constitucional interno, o Tribunal de Justiça está vinculado ao Direito europeu. De facto, o Tribunal de Justiça assumiu muito cedo a função de conferir sistematicidade, ou seja, unidade, a um ordenamento fragmentário, e cujas relações com os ordenamentos internos não estavam claramente definidas nos Tratados fundadores ${ }^{18}$.

\footnotetext{
${ }^{16}$ Cfr. Francisco Balaguer Callejón, “La constitucionalización de la Unión Europea y la articulación de los ordenamientos europeo y estatal”, in Miguel Ángel García Herrera (dir.): El constitucionalismo en la crisis del Estado social, Universidad del País Vasco, Bilbao, 1997, pp. 593-612. Cfr. igualmente, sobre alguns aspectos deste "deficit de constituição” no processo de integração, Ángel Rodríguez, "La Constitucionalización de Europ”, Anuario de la Facultad de Derecho de la Universidad de Extremadura, nº 22 pp. 357-370.

${ }^{17}$ Como indica Gil Carlos Rodríguez Iglesias, os tribunais constitucionais alcançaram, na maioria dos casos, soluções convergentes com as do Tribunal de Justiça, ainda que com fundamentações diferentes, baseadas no seu próprio direito constitucional. Cfr. "Tribunales Constitucionales y Derecho comunitario", in AA.VV., Hacia un nuevo orden internacional y europeo. Estudios en homenaje al profesor Don Manuel Díez de Velasco, Tecnos, Madrid, 1993, p. 1197.

${ }^{18}$ Cfr. Miguel Azpitarte, "Las relaciones entre el Derecho de la Unión y el Derecho del Estado a la luz de la Constitución Europea”, in Revista de Derecho Constitucional Europeo, nº 1, Enero-Junio de 2004, pp. 75-95. Direcção electrónica: http://www.ugr.es/ redce/.
} 
Não é possível desconhecer, dessa perspectiva, o menor nível de desenvolvimento do Direito europeu, do ponto de vista ordenamental, em relação aos Direitos Constitucionais nacionais, já que o princípio de unidade foi um elemento fundamental na configuração do Estado de Direito Constitucional.

De certo modo, também os tribunais constitucionais nacionais desenvolveram uma importante função de reconstrução da unidade do ordenamento, na transição do Estado legal de Direito para o Estado constitucional de Direito. Essa transição encontra o seu símbolo justamente na jurisdição constitucional, pois a partir da sua existência tornou-se possível a reconstrução constitucional da unidade do ordenamento e a realização dos princípios nos quais se baseou o Estado de direito constitucional: pluralismo político (geralmente também territorial) e democracia pluralista, consenso fundamental entre os diversos sectores sociais e garantia jurisdicional desse consenso. A normatividade da Constituição não era um dado, foi também uma obra da jurisdição constitucional.

No entanto, existem diferenças importantes entre o labor que realizam as jurisdições constitucionais e a que realizou e realiza o Tribunal de Justiça. Antes de mais, porque no Estado de direito constitucional, o desenvolvimento constitucional não depende apenas, nem primordialmente, da justiça constitucional. Pelo contrário, é o resultado da interacção entre Constituição, legislação e jurisdição. Essa interacção entre constituinte, legislador e justiça constitucional (em sentido amplo) não existe no âmbito europeu, devido à ausência de referente constitucional, em sentido estrito, e é a debilidade do constituinte e do legislador democrático que provocou um protagonismo muito intenso da jurisdição.

Há que ter em conta, além do mais, que o Tribunal de Justiça não actua apenas sobre uma ordem jurídica fragmentária, mas que actua também (o que não é mais do que a outra face da mesma moeda) sobre uma ordem jurídica em formação. Que a União Europeia tem um sistema jurídico próprio é indubitável. Mas também o é que esse sistema jurídico está ainda em formação no que se refere ao seu nível fundamental. Há que assinalar, porém, que a entrada em vigor do Tratado de Lisboa e, portanto, da Carta dos Direitos Fundamentais da União Europeia, vai contribuir de maneira importante para o desenvolvimento do nível fundamental - constitucional - da União Europeia.

Este carácter dinâmico do processo de integração, correctamente compreendido, deveria ser aplicável, em grande medida, aos ordenamentos constitucionais nacionais. Também estes devem assumir que, num sistema em que convivem diversos ordenamentos constitucionais no mesmo espaço, as transformações de cada um deles afectam os demais e que, portanto, uma ordenação europeia das constituições nacionais implica, entre outras coisas, uma percepção mais dinâmica da revisão constitucional ${ }^{19}$.

${ }^{19}$ Cfr. Francisco Balaguer Callejón, "El status constitucional de la reforma y la fragmentación del Poder Constituyente", in AAVV, La democracia constitucional. Estudios en homenaje al Profesor Rubio Llorente, Congreso de los Diputados, Tribunal Constitucional, Vol. I, Madrid, 2002 e Francisco Balaguer Callejón, "Fuentes del Derecho, espacios constitucionales y ordenamientos jurídicos”, Revista Española de Derecho Constitucional, n. 69, Madrid, 2003, pp. 181-213. 
No entanto, o certo é que durante muito tempo continuará a existir uma diferença essencial entre o ordenamento europeu e os ordenamentos constitucionais nacionais. No primeiro deles, o carácter dinâmico é um traço estrutural próprio de um processo de formação em curso. No segundo é uma condição externa que, além dos processos naturais de adaptação às mudanças sociais, é originada pela sua integração no ordenamento europeu.

A direcção correcta de um processo de integração que queira orientar-se para a construção de um ordenamento jurídico caracterizado pelos traços que contribuem a tornar viável o princípio de segurança jurídica - unidade, coerência e plenitude é o de convergência entre os termos “constitucional” e “europeu”. Isto implica tanto para o ordenamento europeu, quanto para os nacionais. O ordenamento europeu tem que ser mais constitucional e os ordenamentos constitucionais internos mais europeus. Ambas as coisas não são fáceis de conseguir. A primeira a constitucionalização do ordenamento europeu - porque existem muitas resistências sociais, políticas e doutrinais. Na base dessas resistências está o medo da formação de um futuro Estado federal europeu; daí que se defenda a ideia de que se alguma vez existir uma Constituição Europeia será fora do quadro do Estado - inclusive do Estado Federal.

A segunda - a dificuldade para conferir uma orientação europeia aos ordenamentos internos - deriva de diversos factores, entre os quais cabe destacar a inércia própria da consideração estática dos sistemas constitucionais. Com o processo de integração, e pese a ser o modelo básico da construção constitucional da Europa, o Estado de direito constitucional entrou em crise como paradigma da consideração unitária do ordenamento jurídico nas democracias pluralistas. Se essa crise termina com o seu reforço ou com a configuração de um novo paradigma está por ver. De momento, deveríamos tomar nota, os constitucionalistas, de que do mesmo modo que em muitos Estados europeus se produziu a transição do estado legal para o Estado constitucional de Direito, agora estamos numa segunda transição, motivada pelo processo de integração europeia. Uma transição do Estado de direito constitucional para uma nova forma, cujos perfis ainda desconhecemos, mas que se articulará dogmaticamente através do Direito constitucional europeu em formação.

\section{O CONTRIBUTO DO TRATADO DE LISBOA PARA A RELAÇÃO ENTRE O TRIBUNAL DE JUSTIÇA E OS TRIBUNAIS CONSTITUCIONAIS DOS ESTADOS-MEMBROS}

\subsection{A rejeição formal da Constitucionalidade da União Europeia}

Do ponto de vista do desencontro histórico entre os termos “constitucional” e "europeu”, o Tratado de Lisboa supõe um avanço importante no processo de constitucionalização material da União, que contrasta com o repúdio expresso dos símbolos constitucionais. A concepção geral do Tratado de Lisboa não é outra que a pretensão de dissimular, quando não de ocultar, o Direito Constitucional Europeu que se tinha incorporado no Tratado Constitucional e de minimizar, portanto, a constitucionalidade da União Europeia. Trata-se de uma operação tão aberta e evidente, realizada de uma maneira tão pública e publicitada, que resulta extraordinariamente 
paradoxal, já que o habitual é que quando alguém quer ocultar algo, não o realiza de um modo tão óbvio ${ }^{20}$.

Mas, além do mais, esta pretensão foi entrelaçada com o questionamento de todos os elementos que, até de modo simbólico, pudessem apelar à consideração da União Europeia como um Estado ou um "Super-Estado": o Tratado não devia incluir símbolos ou formulações que dessem uma imagem da União Europeia comparável à de um Estado. Em definitivo, foi unida à rejeição frontal da estadualidade da União Europeia. Desse modo, a redução do impacto visual da constitucionalidade foi acompanhada da negação da estadualidade, gerando, involuntariamente, uma conexão entre estadualidade e constitucionalidade que é especialmente interessante do ponto de vista jurídico.

A rejeição da estadualidade manifestou-se já na Declaração da Chanceler Angela Merkel de 14 de Junho de 2007, que não deixava lugar a dúvidas de quais eram os objectivos dos eurocépticos (aceites, ainda que não partilhados, pela Alemanha e pelos Estados europeístas). Depois de apresentar o medo da configuração estatal da União Europeia como um temor específico dos cidadãos europeus a que os EstadosMembros se debilitassem desnecessariamente, afirmará essa Declaração que os símbolos e as denominações similares às dos Estados não se incluiriam no novo Tratado porque alguns Estados-Membros identificavam esses símbolos com a ideia do chamado "Super-Estado" ${ }^{21}$

Posteriormente a esta Declaração, a rejeição da estadualidade e da pretensão de ocultar a constitucionalidade da União Europeia será reafirmada no Conselho Europeu. Serve como exemplo o Anexo I das Conclusões da Presidência do Conselho Europeu de Bruxelas de 21 e 22 de Junho de 2007, no apartado I.3 das Observações Gerais contidas no Mandato da CIG: "O TUE e o Tratado sobre o Funcionamento da União não terão carácter constitucional. Esta mudança reflectir-se-á na terminologia utilizada em todos os textos dos Tratados: não será usado o termo "Constituição”, o "Ministro dos Negócios Estrangeiros da União" será designado Alto Representante da União para os Negócios Estrangeiros e a Política de Segurança, serão abandonadas as denominações "lei" e "lei-quadro", e manter-se-ão as actuais denominações “regulamentos”, “directivas” e "decisões”. De igual modo, nenhum artigo dos Tratados alterados fará alusão aos símbolos da UE, como a bandeira, o hino e o lema.

${ }^{20}$ Cfr. Francisco Balaguer Callejón, "El Tratado de Lisboa en el Diván. Una reflexión sobre constitucionalidad, estatalidad y Unión Europea”, Revista Española de Derecho Constitucional, nº 83, mayo-agosto de 2008. Versão portuguesa: "O Tratado de Lisboa no divã _ Uma reflexão sobre estadualidade, constitucionalidade e União Européia”, Revista Brasileira de Estudos Constitucionais, nº 7, jul./set. 2008.Versão electrónica: http://www.editoraforum.com.br/sist/conteudo/lista_conteudo.asp?FIDT_CONTEUDO=55215

21 “As I am sure you will understand, I cannot anticipate the results of consultations in the Council next week. But one development is already taking shape: state-like designations and symbols will not be included in a new treaty. For too many of our partners, they stand for the so-called European super state, which I mentioned earlier. I do not share this concern, but I have to respect it. After all, we know that it is not always specific content, paragraphs and competences, which move people. It is often a case - in the truest sense of the word - of the self-understanding of states and their citizens”.

Cfr.: http://www.bundesregierung.de/Content/EN/Regierungserklaerung/2007/06/2007-06-14-regierungserkla erung-eu-gipfel_en.html. 
No tocante ao primado do direito da UE, a CIG aprovará uma Declaração remetendo para a actual jurisprudência do Tribunal de Justiça da UE”.

O Tratado de Lisboa evidenciou, definitivamente, a persistência da forte rejeição de alguns Estados-Membros e de alguns sectores de opinião da caracterização formal do processo de constitucionalização da União Europeia (já que este processo seguiu o seu curso do ponto de vista material) através da terminologia específica do Direito constitucional, por medo do carácter performativo de qualidade estatal que se atribui ao Direito constitucional. Essa rejeição pretendia justificar-se com o resultado negativo dos processos referendários do Tratado Constitucional em França e na Holanda. No entanto, uma vez que o único processo referendário celebrado para ratificar o Tratado de Lisboa teve inicialmente um resultado negativo (o referendo da Irlanda de 12 de Junho de 2008, mas não o posterior de 2 de Outubro de 2009) parece claro que o problema não era definir o Tratado como “Constituição”.

Independentemente de esta operação carecer ou não de fundamentação (em face do resultado do primeiro referendo irlandês), o certo é que o medo do Direito constitucional se apresentou expressamente, no Tratado de Lisboa, sob a forma de repúdio a qualquer termo que pudesse recordar, nas normas fundamentais europeias, uma organização estatal. É evidente, porém, que Direito constitucional e Estado não são termos equivalentes. Pelo contrário, há muitos Estados que desconhecem o Direito constitucional (ainda que se tenham dotado de normas que definem expressamente como "Constituição") enquanto que há âmbitos de poder político submetidos plenamente ao Direito constitucional e que não conformam um "Estado”, no sentido clássico do termo.

O temor de uma cultura constitucional que - paradoxalmente - é inseparável da configuração democrática da vida europeia, não é hoje mais do que uma "survivance" cujos efeitos se prolongam graças a uma estrutura institucional e uma mentalidade desfasadas que respondem às exigências do processo de integração durante os seus primeiros cinquenta anos. No entanto, se algo teve de positivo o Tratado de Lisboa é que esse temor se mostrou de uma forma autenticamente aberta e desinibida, reflectindo-se, inclusivamente, nos textos jurídicos fundamentais da União Europeia. Uma rejeição da estadualidade que se apresenta em condições de um claro desajuste histórico porque utiliza como padrão de medida o Estado nacional de finais do século XIX e princípios do século XX. Um tipo de Estado que já não existe dentro da União Europeia. Nem os Estados-Membros são ainda Estados nacionais nesse sentido, nem a União Europeia deixa de ter estadualidade por não ser um Estado nacional.

Ora, na realidade, o que a União Europeia tem já de "Estado”, tem-no apesar de essa estadualidade não ter ido sempre unida à configuração de um espaço democrático, de técnicas eficazes de controlo do poder e garantias dos direitos fundamentais e, portanto, de Direito Constitucional. O autêntico paradoxo da União Europeia é que a incorporação de Direito constitucional não lhe trará mais “estadualidade”, mas sim que, mantendo a que já tem, vai dotar essa estadualidade de um carácter democrático de que hoje carece em medida equiparável aos sistemas democráticos dos Estados-Membros. A polémica é, portanto, absurda: os elementos constitucionais não tornam a União Europeia mais "Estado” do que já é. Pelo contrário, contribuem para desenvolver o 
espaço constitucional europeu e tornar possível o controlo do poder político europeu. Tornam-na "Estado" mais democrático.

4.2. A ruptura da separação radical entre as Ordens Constitucionais Internas e o Sistema Jurídico da União Europeia

Apesar da rejeição formal dos símbolos constitucionais, o Tratado de Lisboa vai reformular e desenvolver, a partir da sua entrada em vigor a 1 de Dezembro de 2009, o Direito constitucional europeu. O novo TUE começará a evidenciar a sua eficácia no que se refere à europeização dos contra-limites, por exemplo ${ }^{22}$, e os juízes terão que começar a colocar-se a questão do alcance da cláusula de garantia do conteúdo essencial dos Direitos Fundamentais, contida no artigo $52^{\circ}, n^{\circ} 1$, da Carta. A constitucionalidade da União Europeia começará a sua interacção dialéctica com a dos Estados-Membros, contribuindo para o desenvolvimento do Direito constitucional europeu em sentido amplo, o Direito constitucional dos diversos espaços constitucionais (europeu, estatal, territorial) na Europa.

O novo Direito Fundamental da União Europeia integrar-se-á, portanto, dentro de uma constitucionalidade plural, com diversidade de espaços constitucionais. Em última instância, o Tratado de Lisboa contribuirá para romper a percepção habitual de separação entre o ordenamento europeu e o ordenamento interno de cada Estado Membro. O alto grau de dependência que se gera entre os diversos espaços constitucionais na Europa incrementar-se-á com o Tratado de Lisboa, de tal maneira que cada vez será mais real que não possamos ver os sistemas constitucionais dos Estados-Membros em perspectiva exclusivamente "nacional”, nem tão-pouco o sistema jurídico da União Europeia numa perspectiva exclusivamente "europeia”, como se tratasse de esferas separadas.

A interacção entre ambos os ordenamentos gerará desenvolvimentos constitucionais, tanto no ordenamento europeu, como nos ordenamentos dos Estados-Membros. Desse modo, como indica o Professor Häberle ${ }^{23}$, será a interacção entre ambas as ordens jurídicas a determinar a Constituição real de cada Estado Membro, que é em parte europeia, em parte interna.

\footnotetext{
${ }^{22}$ Os contra-limites tinham tentado europeizar-se previamente no artigo I-5.1 del Tratado Constitucional e agora no artigo 4.2 TUE, modificado pelo Tratado de Lisboa, que estabelece que a União respeitará a identidade nacional dos Estados, inerente às suas estrutura políticas e constitucionais s fundamentais, também no que se refere à autonomia regional e local. A própria União Europeia reconheceu, portanto, que existe um núcleo constitucional, integrado pelas estruturas políticas e constitucionais fundamenyais dos Estados membros, que debe ser preservado. Abre-se assim o campo para um conflito latente no plano constitucional entre os Estados membros e a União Europeia, que permite equacionar a possível flexibilização do princípio do primado. Não é, porém, uma questão fácil, já que do princípio do primado depende a própria existência da União como ordenamento jurídico. Por esse motivo, o conflito constitucional continua a carecer de uma solução fácil.

${ }^{23}$ Peter Häberle, ¿Tienen España y Europa una Constitución? Versão espanhola de Miguel Azpitarte Sánchez, com Prólogo de Ángel López López, Fundación El Monte, Sevilla, 2004. Cfr. igualmente, P. Häberle, “Europa - eine Verfassungsgemeinschaft?”, in P. Häberle, Europäische Verfassungslehre in Einzelnstudien, Nomos Verlagsgesellschaft, Baden-Baden, 1999, pp. 84 e ss. Também, P. Häberle, "Europa como comunidad constitucional en desarrollo” Versão espanhola de Francisco Balaguer Callejón, Revista de Derecho Constitucional Europeo, $\mathrm{n}^{\circ}$ 1, Enero-Junio de 2004, pp. 11-24. http://www.ugr.es/ redce/ e P. Häberle, Europäische Verfassungslehre, 5.Auflage, Nomos/Dike, Baden-Baden/Zürich/St. Gallen, 2008.
} 
Um papel fundamental neste processo dialéctico corresponde à Carta dos Direitos Fundamentais da União Europeia. Apesar das limitações políticas do espaço público europeu, a Carta contribuirá para a dilatação de um espaço público cidadão a nível europeu, de um âmbito de discussão sobre as políticas públicas europeias e de um poderoso instrumento de interpretação aberta ${ }^{24}$ do Direito constitucional europeu. O debate constitucional europeu passará do teórico ao concreto e ver-se-á impulsionado pelo potencial conflitivo inerente ao exercício dos direitos dos cidadãos.

Não devemos estranhar, portanto, que a Carta tenha sofrido os piores ataques por parte dos sectores eurocépticos no processo de elaboração do Tratado de Lisboa. A sua deslocação para uma espécie de "limbo" jurídico no qual finalmente adquiriu o mesmo valor dos Tratados a partir da remissão operada pelo artigo $6^{\circ}, n^{\circ} 1$, TUE e o Protocolo sobre a sua aplicação ao Reino Unido e Polónia (e também à República Checa) são uma boa amostra das resistências que despertou. Por mais que as objecções não tenham resultado em nada (do ponto de vista da eficácia jurídica da Carta) não se pode desconhecer a profunda carga simbólica que está por trás destas operações.

Na entrada em vigor da Carta está a semente da definitiva constitucionalização da União Europeia. A Carta estabelecerá um vínculo directo entre as instituições europeias e a cidadania, reforçando a conformação de um status jurídico próprio da cidadania europeia e contribuindo para a configuração de uma específica identidade constitucional europeia.

5. AS CONDIÇÕES ESTRUTURAIS DO DIÁLOGO ENTRE OS TRIBUNAIS CONSTITUCIONAIS E O TRIBUNAL DE JUSTIÇA

Enquanto o processo de constitucionalização avança, a ausência de convergência entre os termos “constitucional” e "europeu” pode gerar obstáculos para o diálogo ou a cooperação entre os tribunais constitucionais e o Tribunal de Justiça ${ }^{25}$. Dissemos antes que ambos falam, de momento, linguagens distintas, a do direito constitucional e a do direito europeu, o que dificulta muito a relação porque o diálogo precisa de um idioma (neste caso, jurídico) comum.

Mesmo reconhecendo que a linguagem do Tribunal de Justiça contém uma orientação constitucional e a dos tribunais constitucionais uma orientação europeia, o problema continua a estar presente. É, além do mais, um problema que não pode ser totalmente resolvido pelos tribunais, por muita vontade que tenham de o fazer, porque depende em grande medida de condições estruturais externas. Algumas delas são de carácter processual e podem favorecer esse diálogo, não há dúvida. É o caso do eventual recurso por parte dos tribunais constitucionais à questão prejudicial ${ }^{26}$.

\footnotetext{
${ }^{24}$ Cfr. Peter Häberle, “Die offene Gesellschaft der Verfassungsinterpreten”, JZ, 1975.

${ }^{25}$ Sobre o diálogo entre os tribunais constitucionais e o Tribunal de Justiça, cfr. Miguel Azpitarte, El Tribunal Constitucional ante el control del Derecho comunitario derivado, Editorial Civitas, Madrid, 2002; Jörg Luther, "Jueces europeos y jueces nacionales: la Constitución del diálogo", in Revista de Derecho Constitucional Europeo, $\mathrm{n}^{\circ}$ 3, Enero-Junio de 2005, pp. 159-181. Direcção electrónica: http://www.ugr.es/ redce/; Tania Groppi, in Revista de Derecho Constitucional Europeo, $\mathrm{n}^{\circ}$ 5, Enero-Junio de 2006. Direcção electrónica: http://www.ugr.es/ redce/, pp. 225-243.

${ }^{26}$ Cfr. Miguel Azpitarte, El Tribunal Constitucional ante el control del Derecho comunitario derivado, cit. Cfr. igualmente, Ricardo Alonso García, Justicia Constitucional y Unión Europea, Civitas, Madrid, 2005.
} 
Mas não devemos esquecer que as condições mais importantes não são de carácter formal, mas sim substancial. Não se referem aos instrumentos do diálogo, mas sim à sua possibilidade material, à identidade do veículo essencial: uma linguagem jurídica comum, o Direito constitucional europeu.

É justamente o carácter deficitário do Direito constitucional europeu, na sua vertente constitucional no âmbito europeu e na sua vertente europeia no âmbito constitucional interno dos Estados-Membros, o que dificulta a construção de uma linguagem jurídica comum. Essa dificuldade tem origem, sobretudo, em condições que são em parte alheias à vontade política dos líderes europeus, especialmente do Tribunal de Justiça e dos tribunais constitucionais internos. Outras, porém, estão dentro da capacidade que os distintos agentes têm de promover uma integração europeia cada vez mais intensa e cada vez mais assente sobre princípios constitucionais.

As condições estruturais externas são de todos conhecidas: a ausência de um espaço público europeu consolidado, a ausência de uma comunidade política europeia e as dificuldades para chegar a esse resultado que derivam das múltiplas assimetrias da actual União Europeia; assimetrias que se vão intensificando à medida que avança o processo de ampliação: no que se refere à população ao território, situação económica, valores culturais, sistema político, sistema constitucional, forma de governo, forma de estado, língua, sistema jurídico, etc. ${ }^{27}$

Essas condições estruturais externas são um ponto de partida que não devemos ocultar e dificultam enormemente a configuração de uma comunidade política europeia. É necessário advertir, porém, que algumas delas se vêem reduzidas pelas dinâmicas dos últimos anos e que outras são muito discutíveis, dependendo da perspectiva nacional que se adopte. Por exemplo, a necessidade de um "povo europeu” para construir uma comunidade política europeia e uma identidade europeia não se percebem do mesmo modo na Alemanha e em Espanha, ou quem sabe em Itália. Sociedades nas quais existem diversas estruturas nacionais compreendem melhor a dificuldade que pode ter o constitucionalismo actual para continuar a pensar em termos de uma correspondência absoluta entre "nação" e "Estado". Igualmente, na medida em que a imigração define uma realidade multicultural e multiétnica em muitas sociedades europeias, o conceito de "povo" revela-se insuficiente para garantir uma ordenação democrática do poder. Pelo contrário, se partirmos da ideia de cidadania, necessariamente reformulada e privada do seu sentido nacional, podemos pensar seriamente na configuração de uma comunidade política europeia e de uma identidade europeia, enquanto identidade cidadã.

Por outro lado, dependendo das orientações que sigam os agentes políticos e jurídicos europeus, todas estas divergências podem ver-se acrescidas, dificultando o processo de integração, ou reduzidas, tornando-o mais viável. Entramos assim num segundo tipo de condições estruturais que já não são externas enquanto condições

${ }^{27}$ Cfr. Dieter Grimm, “Braucht Europa eine Verfassung?”, 1994, versão italiana “Una costituzione per l'Europa?”, in Il futuro della costituzione, org. de Gustavo Zagrebelsky, Pier Paolo Portinaro, Jörg Luther, Einaudi, Torino, 1996, pp. 339-367. Cfr. igualmente, F. Balaguer Callejón, "Die europäische Verfassung auf dem Weg zum Europäischen Verfassungsrecht”, in Jahrbuch des öffentlichen Rechts der Gegenwart, Mohr Siebeck, Tübingen, Bd. 53, 2005, pp. 401-410. 
objectivas que se projectam sobre a actividade dos agentes europeus e estaduais, mas que dependem, em grande medida, da vontade desses mesmos agentes. Neste ponto, desgraçadamente, é onde se pode ser menos optimista. Não só porque as dinâmicas actuais dos processos políticos internos retroalimentam a distância entre a cidadania e o processo de integração, mas também porque resulta evidente, ainda, o interesse dos agentes políticos em favorecer essas dinâmicas e em controlar a chave estatal interna no processo de integração.

Em todo o caso, são muitos os âmbitos nos quais poderiam melhorar-se as condições estruturais a que está submetida a relação entre o Tribunal de Justiça e as jurisdições constitucionais. Ainda que não seja possível alcançar para já uma linguagem jurídica comum própria de um Direito constitucional europeu consolidado, podem procurar-se fórmulas que favoreçam as condições de desenvolvimento de uma interacção produtiva entre ambas as jurisdições. Para tal, haveria que actuar nos dois níveis implicados, tornando o Direito constitucional interno mais europeu e o Direito europeu mais constitucional:

a) Do ponto de vista do Direito constitucional nacional, é necessário, em primeiro lugar, uma mudança de perspectiva em relação à atitude geral que alguns tribunais constitucionais têm tido a respeito do Direito europeu. É preciso admitir que a interacção entre Direito europeu e direito interno não permite traçar uma linha "defensiva" no âmbito interno que impeça a penetração do Direito europeu. Por exemplo, em relação ao princípio da autonomia institucional, os tribunais constitucionais deveriam reconhecer que o Direito europeu está a incidir na divisão interna de competências e que elidir o problema não contribui para o resolver ${ }^{28}$.

Em segundo lugar, negar carácter constitucional à aplicação interna do Direito europeu, como fizeram alguns tribunais constitucionais, não parece muito congruente com a ordem constitucional e não favorece a relação dialéctica entre Direito europeu e Direito constitucional interno. Sob uma Constituição normativa, qualquer violação do Direito europeu é claramente uma violação da ordem constitucional interna. Posto que é a Constituição que confere validade ao Direito europeu, a violação do Direito europeu é também uma violação da Constituição. Questão distinta é que essa violação deva ser julgada pelos tribunais constitucionais. O juízo de validade por parte dos tribunais constitucionais não é necessário, uma vez que o Direito europeu afasta o interno em virtude do princípio do primado que actua no plano da eficácia das normas e não da sua validade ${ }^{29}$.

Em terceiro lugar, uma maior flexibilidade, homogeneidade e orientação europeia dos ordenamentos nacionais seria muito positiva. O estabelecimento de procedimentos mais flexíveis de revisão tornaria possível uma maior capacidade de adaptação às condições próprias de um pluralismo ordenamental nas que é costume ser necessário

\footnotetext{
${ }^{28}$ Cfr. Francisco Balaguer Callejón, "El status constitucional de la reforma y la fragmentación del Poder Constituyente”, cit., pp. 99-130. Por referência a Itália, cfr. Gil Carlos Rodríguez Iglesias, “Tribunales Constitucionales y Derecho comunitario”, cit. p.1191, nota 78.

${ }^{29}$ Cfr. Francisco Balaguer Callejón, "La constitucionalización de la Unión Europea y la articulación de los ordenamientos europeo y estatal”, cit., pp. 593-612.
} 
dar resposta em cada espaço constitucional (europeu, estatal, territorial) às mudanças que se produzem nos restante, especialmente na relação entre espaço europeu/estatal e entre espaço estatal/territorial. Por outro lado, a maior homogeneidade - dentro do respeito pelo pluralismo e pelas singularidades dos ordenamentos nacionais - e a sua orientação europeia facilitariam o labor dos tribunais constitucionais e a sua relação com o Tribunal de Justiça. A este respeito, há que ter em conta também a necessidade de incorporar novas perspectivas metodológicas próprias do Direito constitucional europeu, tais como o recurso ao Direito comparado como método de interpretação jurídica $^{30}$, e ao desenvolvimento gradual dos textos ${ }^{31}$, de acordo com as formulações de Peter Häberle.

B) Da perspectiva do Direito europeu, é preciso reconhecer, em primeiro lugar, que uma Constituição europeia não pode articular-se de modo fragmentário e sem uma correspondência clara com os elementos nucleares do Direito constitucional dos Estados-Membros. São esses princípios nucleares que permitem definir uma ordem comum de valores na qual deve inspirar-se a futura ordenação constitucional da Europa. É necessário ter em conta que não é coerente o medo da Constituição que se percebe hoje nas altas instâncias europeias e em alguns sectores doutrinais com o alto valor que se outorga à Constituição no interior dos Estados-Membros. O poder público que se exerce sobre a cidadania não pode estar submetido a regras constitucionais num âmbito (o nacional) e não constitucionais noutro âmbito (o europeu).

Em segundo lugar, partindo das actuais necessidades constitucionais da Europa, é preciso promover, de maneira decidida, o desenvolvimento do processo de constitucionalização. Todavia, este processo não pode basear-se apenas em actuações normativas (como o Tratado de Lisboa e a entrada em vigor da Carta), mas deve atender também ao desenvolvimento de um espaço constitucional de decisão a nível europeu. Isso implica actuações sérias de promoção de um espaço público europeu, de partidos políticos e agentes políticos a nível europeu e de meios de comunicação a nível europeu. No nível alcançado pelo processo de integração, todas estas actuações fazem parte, necessariamente, do próprio processo de constitucionalização, porque permitem gerar o substrato material sobre o qual a Constituição e a cultura constitucional europeia poderão assentar-se e criar raízes. Um espaço político e constitucional europeu também é necessário para que a interacção entre as jurisdições possa ser produtiva e para contribuir para gerar uma autêntica comunidade europeia de juristas.

\footnotetext{
${ }^{30}$ Cfr. Peter Häberle, “Grundrechtsgeltung und Grundrechtsinterpretation im Verfassungsstaat - Zugleich zur Rechtsvergleichung als "fünfter" Auslegungsmethode“, cit. Cfr. igualmente Paolo Ridola, "La giurisprudenza costituzionale e la comparazione“, 2006, http://www.associazionedeicostituzionalisti.it/materiali/anticipazioni/ giurisprudenza_comparazione/index.html; Angioletta Sperti, "Il dialogo tra le corti costituzionali ed il ricorso alla comparazione giuridica nella esperienza più recente“, in http://www.associazionedeicostituzionalisti.it/ materiali/anticipazioni/comparazione/index.html. e, da mesma autora: "I giudici costituzionali e la comparazione giuridica”, na imprensa, in Giornale di storia costituzionale. Da perspectiva das fontes do Direito, cfr. Alessandro Pizzorusso, Comparazione giuridica e sistema delle fonti del Diritto, G. Giappichelli Editore, Torino, 2005.

${ }^{31}$ Cfr. Peter Häberle, “Textstufen als Entwicklungswege des Verfassungsstates“, 1989, na compilação do mesmo autor Rechtsvergleichung im Kraftfeld des Verfassungsstaates. Methoden und Inhalte, Kleinstaaten und Entwicklungsländer, Duncker \& Humblot, Berlín, 1992, pp. 3-26.
} 
Em terceiro lugar, favorecer a integração constitucional da Europa supõe também atender ao trabalho desenvolvido pelos tribunais constitucionais nacionais, aos seus métodos de trabalho e às suas elaborações jurisprudenciais. À medida em que o nível europeu se conforme como uma ordenação constitucional em todos os âmbitos, mais necessárias resultarão a experiência previamente desenvolvida pelos tribunais constitucionais e as técnicas de controlo da constitucionalidade que tenham ido perfilando.

\section{REFERÊNCIAS}

AZPITARTE, Miguel. El Tribunal Constitucional ante el control del Derecho comunitario derivado. Editorial Civitas: Madrid, 2002.

Las relaciones entre el Derecho de la Unión y el Derecho del Estado a la luz de la Constitución Europea. Revista de Derecho Constitucional Europeo. N ${ }^{\circ}$ 1, jan-jun. 2004, pp. 75-95.

CALLEJÓN, Francisco Balaguer. La constitucionalización de la Unión Europea y la articulación de los ordenamientos europeo y estatal. GARCÍA HERRERA, Miguel Ángel (Coord.). El constitucionalismo en la crisis del Estado social. Universidad del País Vasco: Bilbao, 1997.

El status constitucional de la reforma y la fragmentación del Poder Constituyente. In: La democracia constitucional. Estudios en homenaje al Profesor Rubio Llorente. Congreso de los Diputados, Tribunal Constitucional, Vol. I, Madrid, 2002.

Fuentes del Derecho, espacios constitucionales y ordenamientos jurídicos. Revista Española de Derecho Constitucional. N 69, Madrid, 2003, pp. 181-213.

Livelli istituzionali e tecniche di riconoscimento dei diritti in Europa. Una prospettiva costituzionale. In: ROLLA, Giancarlo (Org.). Tecniche di garanzia dei diritti fondamentali. G. Giappichelli Editore: Torino, 2001. (versão portuguesa: Revista Seqüência, Universidade Federal de Santa Catarina. Ano XXV, nº 50, Jul. 2005, pp. 237-258).

El Tratado de Lisboa en el Diván. Una reflexión sobre constitucionalidad, estatalidad y Unión Europea. Revista Española de Derecho Constitucional. nº 83, maio-ago. 2008. (Versão portuguesa: O Tratado de Lisboa no divã - Uma reflexão sobre estadualidade, constitucionalidade e União Européia. Revista Brasileira de Estudos Constitucionais. № 7, jul-set. 2008. Disponível em: http://www.editoraforum.com.br/sist/conteudo/lista_conteudo.asp?FIDT_CONTEUDO=55215 Acessado em: 21 jan. 2011).

CRISAFULLI, V. Atto normativo. EdD. Tomo IV. Milão, 1959, pp. 258-260.

Disposizione (e norma). EdD. Tomo XIII. Milão, 1964.

FERRAJOLI, Luigi. Más allá de la soberanía y de la ciudadanía: un constitucionalismo global. ISONOMÍA, n. 9, oct. 1998.

GARCÍA, Ricardo Alonso. Justicia Constitucional y Unión Europea. Civitas: Madrid, 2005.

GRIMM, Dieter. Una costituzione per l'Europa? In: ZAGRABELSKY, Gustavo et al. (Orgs.). Il futuro della costituzione. Einaudi: Torino, 1996.

GROPPI, Tania. Revista de Derecho Constitucional Europeo. No 5, jan-jun. 2006, pp. 225-243.

HÄBERLE, Peter. Die offene Gesellschaft der Verfassungsinterpreten. Juristen Zeitung, 1975.

Textstufen als Entwicklungswege des Verfassungsstates. In: HÄBERLE, Peter. Rechtsvergleichung im Kraftfeld des Verfassungsstaates. Methoden und Inhalte, Kleinstaaten und Entwicklungsländer. Duncker \& Humblot: Berlim, 1992. 
Europa - eine Verfassungsgemeinschaft?. In: HÄBERLE, Peter. Europäische Verfassungslehre in Einzelnstudien. Nomos Verlagsgesellschaft: Baden-Baden, 1999.

• ¿Tienen España y Europa una Constitución? Fundación El Monte: Sevilla, 2004.

. Europa como comunidad constitucional en desarrollo. Revista de Derecho Constitucional Europeo. No 1, jan-jun. 2004, pp. 11-24.

Europäische Verfassungslehre. 5. ed. Nomos/Dike: Baden-Baden/Zürich/St. Gallen, 2008.

IGLESIAS, Gil Carlos Rodríguez. Tribunales Constitucionales y Derecho comunitario. Hacia un nuevo orden internacional y europeo. Estudios en homenaje al profesor Don Manuel Díez de Velasco. Tecnos: Madrid, 1993.

; CRUZ, Julio Baquero. Funciones constitucionales del Tribunal de Justicia de las Comunidades Europeas. Fundamentos. № 4, Junta General del Principado de Asturias, 2006.

LA PERGOLA, Antonio. El Juez Constitucional italiano ante la primacía y el efecto directo del derecho comunitario. Notas sobre unas jornadas de estudio. In: COLNERIC, Ninon et al. (Orgs.). Une communauté de droit. Festschrift für Gil Carlos Rodríguez Iglesias. Berliner Wissenschafts Verlag: Berlin, 2003.

LANCHESTER, Fulco. La Carta europea dei diritti fondamentali tra aspirazioni e realtà. In: Sfera pubblica e Costituzione europea. Carocci editore: Roma, 2002.

LLORENTE, Francisco Rubio; JUNCO, José Alvarez (Eds.). El informe del Consejo de Estado sobre la reforma constitucional. Texto del informe y debates académicos, CEPC: Madrid, 2006. LÓPEZ, Enrique Guillén. El Parlamento Europeo. Revista de Derecho Constitucional Europeo. No 3, jan-jun. 2005, pp. 57-85.

LUTHER, Jörg. Jueces europeos y jueces nacionales: la Constitución del diálogo. Revista de Derecho Constitucional Europeo. N ${ }^{\circ}$ 3, jan-jun. 2005, pp. 159-181.

PINELLI, Cesare. Multilevel Constitutionalism e principi fondativi degli ordinamenti sopranazionali. Disponível em: http://www.giuripol.unimi.it/eventi/Pinelli\%20Milano.pdf. Acessado em: 21 jan. 2011.

PIZZORUSSO, Alessandro. Comparazione giuridica e sistema delle fonti del Diritto. G. Giappichelli Editore: Torino, 2005.

RIDOLA, Paolo Ridola. La giurisprudenza costituzionale e la comparazione. 2006. Disponível em:

http://www.associazionedeicostituzionalisti.it/materiali/anticipazioni/giurisprudenza_comparaz ione/index.html. Acessado em: 21 jan. 2011.

RODRÍGUEZ, Ángel. La Constitucionalización de Europa. Anuario de la Facultad de Derecho de la Universidad de Extremadura. № 22 pp. 357-370.

SPERTI, Angioletta. Il dialogo tra le corti costituzionali ed il ricorso alla comparazione giuridica nella esperienza più recente. Rivista di diritto costituzionale. Aceito para publicação. Disponível em: http://www.associazionedeicostituzionalisti.it/materiali/anticipazioni/comparazione/ index.html. Acessado em: 21 jan. 2011.

I giudici costituzionali e la comparazione giuridica. Giornale di storia costituzionale. Aceito para publicação.

VILLALÓN, Pedro Cruz. El papel de los tribunales constitucionales nacionales en el futuro constitucional de la Unión. In: VILLALÓN, Pedro Cruz (Org.). La Constitución inédita. Estudios ante la constitucionalización de Europa. Editorial Trotta: Madrid, 2004. 
. La Constitución inédita. La dificultad del debate constitucional europeo. In: VILLALÓN, Pedro Cruz (Org.). La Constitución inédita. Estudios ante la constitucionalización de Europa. Editorial Trotta: Madrid, 2004.

VILLAR, Gregorio Cámara Villar. Los Derechos Fundamentales en el proceso histórico de construcción de la Unión Europea y su valor en el Tratado Constitucional. Revista de Derecho Constitucional Europeo. N ${ }^{\circ}$ 4, jul-dez. 2005, pp. 9-42.

WEILER, J.H.H. El principio de tolerancia constitucional: la dimensión espiritual de la integración europea. In: CALLEJÓN, Francisco Balaguer (Coord.). Derecho constitucional y cultura. Estudios en Homenaje a Peter Häberle. Tecnos: Madrid, 2004. 